\title{
Locally Produced Agricultural By-Products as Feed Sources for Pigs
}

\begin{abstract}
Keywords: Raw fiber concentrates; Agricultural by-products; Cellulose content; Animal health

Abstract

Raw fiber concentrates, products with high content in cellulose hemicellulose and lignin, are new sources of concentrates with high biological and functional value. Recent studies have demonstrated that raw fiber concentrated products have a positive influence on intestinal development, in health status of piglets and in sows. Agricultural by-products with high lignocellulose content are commonly used as supplementary feeds for animals and with their low or zero cost can also improve the economic efficiency of animal production. The materials that have been studied in this work currently are wasted or in best case are used as pellets fuel.

In order to explore these potentials a series of by-products were investigated: walnut shell, olive kernel, grape branches, woody parts of oregano, corn cobs, corn stalks, woody parts of potato, cotton stems, sawdust mix of oak, spruce and pine and cottonseed fiber. The quality of those by-products is evaluated after a series of classical feed analysis. Samples were collected from the region of Thessaly in Greece. The chemical composition of these by-products was determined in order to develop a proper feeding system for livestock. Our results showed high availability and lignocellulose content in a lo of by-products. These should be used to produce concentrated raw fiber feeds in order to improve the animal production and farmers' livelihood.
\end{abstract}

\section{Introduction}

The intensive system of livestock production and the high cost of conventional feeds have aroused interest in the search for cheaper feedstuffs as substitutes. Agro-industrial by-products which are generated in large amounts every year would be an excellent choice in conventional diets for the animals due to their availability, their low cost, and their constituents (proteins, minerals, vitamins and trace elements). Countries according to the environmental legislation should seriously take into consideration the economic benefits that result from the use of these by-products [1-4]. Several studies have demonstrated that when sows are fed with raw fiber (high content in cellulose hemicellulose and lignin) there is a positive influence on their health status [5-7].

Cellulose is a major structural component of plant cell walls, which is responsible for mechanical strength. It is made up of a linear polymer chain, which in turn consists of a series of hydroglucose units in glucan chains. The hydroglucose units are held together by 1-4 glycosidic linkages, producing a crystalline structure that can be broken down more readily to monomeric sugars. Hemicellulose macromolecules are repeated polymers of pentoses and hexoses and thus can be a source of various polysaccharides, like xylose, galactose, mannose and arabinose. It has been also reported [8] that hemicellulose water holding capacity is greater to that of cellulose. Lignin is a complex polymer of aromatic alcohols known as monolignols. Lignin contains three aromatic alcohols (coniferyl

\section{Journal of}

Veterinary Science \& Medicine

\author{
Kostas Katsoulis ${ }^{1}$, Leonidas Leontides ${ }^{2}$ and \\ George Kontopidis ${ }^{1 *}$
}

${ }^{I}$ Department of Biochemistry, Faculty of Veterinary Medicine, University of Thessaly, Trikalon 224, Karditsa, 4313-1, Greece ${ }^{2}$ Department of Epidemiology, Biostatistics and Animal Health Economics, Faculty of Veterinary Medicine, University of Thessaly, Trikalon 224, Karditsa, 4313-1, Greece

*Address for Correspondence

George Kontopidis, Department of Biochemistry, Faculty of Veterinary Medicine, University of Thessaly, Trikalon 224, Karditsa, 4313-1, Greece, Tel: +302441066017; Fax: +30 24410 66041; E-mail: gkontopidis@vet.uth.gr

Submission: 14 March, 2016

Accepted: 09 May, 2016

Published: 13 May, 2016

Copyright: $\odot 2016$ Katsoulis K, et al. This is an open access article distributed under the Creative Commons Attribution License, which permits unrestricted use, distribution, and reproduction in any medium, provided the original work is properly cited.

Reviewed \& Approved by: Dr. Efterpi Christaki, Faculty of Veterinary Medicine, Aristotle University of Thessaloniki, Greece

alcohol, sinapyl alcohol and coumaryl alcohol) that are produced through a biosynthetic process and forms a protective seal around the other two components [9-11].

Feeds may be classified as concentrates and roughages, depending on their composition. Concentrates contain a high density of digestible nutrients (crude fiber content less than $18 \%$ of dry matter). The term raw fiber concentrates describes raw fiber ingredients with at least $60 \%$ raw fiber content. This is mostly achieved by the use of concentration processes, which can be of a physical or thermomechanical nature. Raw fiber concentrates are new sources of fiber concentrate with high biological and functional value; they can be mixed in concentrated high-energy ratio for sows and they increase the fiber content of the diet without significantly reducing its energy content [12-14]. The beneficial effects of high-fiber concentrated feedstuffs have been shown in several studies $[15,16]$. High fiber diets appear to promote resting behavior in sows and indirectly results in a reduction in aggressive behavior in group housing systems [1723]. Dietary fiber has been shown to prolong postprandial satiety, to increase welfare and to reduce stereotypic behaviors in pigs by reducing feeding motivation [24]. Raw fiber has a satiation effect on sows, which in turn has a calming effect. Therefore the addition of raw fiber to the diet reduces aggressive behavior and fights when pregnant sows are housed in groups. The water holding capacity (WHC), describes the ability of feed to bind water under atmospheric pressure and it is particularly important for effective digestion. In addition raw fibers reduce the feed intake in ad libitum feeding systems in order to prevent too much weight gain. Therefore the satiation effect occurs very quickly and with the dosage of raw fiber concentrates the desired feed intake can be regulated [17]. Also, calves fed with raw fiber concentrate had better fecal score than the control group in the entire experimental period. These observations could be due to the increased role of raw fiber concentrate in peristalsis movements of 
intestine; raw fiber contents in sow can speed up the intestinal transit time of the digestion by up to $40 \%$ [25]. Dietary (raw) fiber is also the main substrate of intestinal bacteria. Pig's microbiota contains highly active cellulolytic bacterial species, including Fibrobacter intestinalis, Butyrivibrio spp., Ruminococcus spp. [26,27]. Soluble (pectins, gums, $\beta$-glucans) and insoluble (cellulose) dietary fibers can be degraded by intestinal bacteria producing volatile fatty acids; when they are absorbed from the large intestine they may provide up to $30 \%$ of the energy requirement for maintenance in growing pigs [28]. The higher fermentability of soluble fiber can be attributed to its higher waterholding capacity allowing bacteria to easily penetrate the matrix and start degradation. Thus, with diets containing high soluble fiber levels, the activity of bacteria with cellulolytic and hemicellulolytic activities is generally increased [29].

In addition to the benefits that result from the raw fiber use, some of these by-products are also a source of fats and minerals. In particular, fats can be utilized not only to provide energy but fatsoluble vitamins and essential fatty acids. Also minerals are necessary to maintain body function, to optimize growth and reproduction and to stimulate immune response [30-32]. Another significant parameter of an animal feed is acid binding capacity (ABC) since it can affect the procedure of digestion. Different components in animal feed can change the $\mathrm{ABC}$ of the feed, which is important in pigs and poultry. Feed components with high $\mathrm{ABC}$ values can absorb a lot of $\mathrm{H}^{+}$. As a result the $\mathrm{pH}$ of the stomach and the proximal digestive tract will remain high $[33,34]$. Local agricultural by-products could be used for the production of concentrated raw fiber products for animal diet. Initially, the objective of this study was to identify agro by-products available for livestock feeding as well as to suggest the most suitable by-product or by-product combination that fits the characteristics of the commercially available products.

\section{Materials and Methods}

\section{Materials}

The agricultural by-products that used for the research work were obtained during 2013-2014 from the region of Thessaly in Greece. The following by-products were investigated: walnut shell, olive kernel, grape branches, woody parts of oregano, corn cobs, corn stalks, woody parts of potato, cotton stems, sawdust mix of oak, spruce and pine and cottonseed fiber. Acid detergent fiber (ADF), neutral detergent fiber (NDF), lignin, ether extract (EE), ash content, $\mathrm{pH}$, acid binding capacity $(\mathrm{ABC})$ and water holding capacity (WHC) were determined.

\section{Methods}

The samples initially were purified from impurities, little stones and tracks of dust. Laboratory sample preparation was needful in order to convert the sample into a homogeneous material suitable for analysis. Before grinding, the biggest parts of samples were cut and divided in smaller. Drying samples grinded in a mill (System POLYMIX" PX-MFC 90 D) into smaller particles using sieve with 1-2 mm wide openings [35]. Drying of samples (approximately $2 \mathrm{~g}$ ) was obtained by heating in a drying oven (model R. Espinar, S.L.) at 100$103{ }^{\circ} \mathrm{C}$ until constant weight was obtained between two sequential measurements [36].
$\mathrm{pH}$ measurements were made using a digital laboratory $\mathrm{pH}$ meter (model WTW $\mathrm{pH} 525$ ) which was calibrated using certified $\mathrm{pH}=4.0$ and $\mathrm{pH}=7.0$ buffer solutions, according to official method [35]. About $10 \mathrm{~g}$ of each sample were weighted and swirled in $90 \mathrm{ml}$ of distilled water for $30 \mathrm{~min}$ and after standing the $\mathrm{pH}$ was measured. The ether extract (EE) was determined using method of Soxhlet. Approximately $5 \mathrm{~g}$ of solid sample were mixed with anhydrous sodium sulfate, placed in an extraction thimble and were extracted using an appropriate solvent in the Soxhlet extractor. The distilled solvent was condensed and in final drying step the remaining traces of solvent was evaporated from the boiling flask. The mass of the extract (total fat) was measured after subtracting initial from final weight of the boiling flask [37]. Ash contents were determined using dry ashing method. The samples (5 g) were ashed for about $8 \mathrm{hr}$ until a white or grey ash residue had been obtained using a furnace (model P. Selecta, $3000 \mathrm{~W}$ ) where temperature had been gradually increased from room temperature to $450{ }^{\circ} \mathrm{C}$ in $1 \mathrm{~h}$ [36].

Acid detergent fiber (ADF), neutral detergent fiber (NDF) and lignin were determined according to [37] using an extraction unit for determining raw fiber content (model DOSI-FIBER-P. SELECTA). NDF is the amount of substances obtained from residue after boiling of sample (1-2 g) with neutral detergent solution. NDF residue contains hemicellulose, cellulose, lignin, cutin, insoluble mineral substances and some proteins of cell walls. ADF is the amount of substances obtained from residue after boiling of sample with acid detergent solution. ADF residue contains cellulose, lignin, cutin and by mineral substances insoluble in an acid environment (silica). The difference between NDF and ADF is given mostly by hemicelluloses.

$\mathrm{ABC}$ was calculated as the amount of acid in milliequivalents (meq) required lowering the $\mathrm{pH}$ of $1 \mathrm{~kg}$ of sample to $\mathrm{pH} 4.0$ (ABC4). The acid binding capacity was measured according to [38]. A 10 g sample was suspended in $90 \mathrm{ml}$ of distilled water and continuously stirred with a magnetic stirrer. Titrations were performed by addition of acid $(0.1 \mathrm{~N} \mathrm{HCl})$ in variable increments. Acid was added so that it would take approximately 10 separate additions of acid to reach $\mathrm{pH}$ 4.0. Initial $\mathrm{pH}$ and all further readings taken during the titration were recorded after equilibration for three minutes [33,39]. Water holding capacity (WHC) was analyzed using an adaptation of the filtration method [40]. A dry sample $0.5 \mathrm{~g}$ was soaked in $200 \mathrm{ml}$ of distilled water for $24 \mathrm{~h}$ at room temperature and then filtered through Whatman No.1 filter paper. Samples were filtered rapidly and filtration was completed after $10 \mathrm{~min}$. A sample of the residue was weighed (wet weight) before drying overnight in an oven at $105{ }^{\circ} \mathrm{C}$ and reweighed (dry weight) which gave WHC.

Thirty samples have been analyzed for the data present in Table 1 (three samples for each by-product). Twenty one samples have been analyzed for the data present in Table 2 (three samples for each byproduct).

\section{Statistical analysis}

Initially, all data from the analyses previously described were summarized. Then, the medians of the ADF, NDF and lignin percentage were compared among all the agricultural by-products considered by the $\mathrm{K}$-sample equality-of-medians test. The same test was used to compare the medians of the WHC, $\mathrm{pH}$ and $\mathrm{ABC}$ among 
Table 1: Chemical characterization (median (range)) of the investigated by-products.

\begin{tabular}{|c|c|c|c|c|c|}
\hline By-product & EE & ADF & NDF & Lignin & ASH \\
\hline Walnut Shell & $0.7(0.6,0.8)$ & $52.7(50.6,54.7)$ & $77.3(75.3,79.4)$ & $36.7(33.8,39.5)$ & $3.2(2,4.5)$ \\
\hline Olive Kernel & $8.4(7.9,8.9)$ & $43.0(40.8,45.2)$ & $59.3(55.1,63.5)$ & $27.0(24.4,29.6)$ & $3.4(2.1,4.6)$ \\
\hline Grape Branches & $1.5(1,2)$ & $\begin{array}{c}42.0 \\
(39.8,44.2)\end{array}$ & $67.0(64.8,69.2)$ & $\begin{array}{c}27.7 \\
(25.1,30.2)\end{array}$ & $1.5(1.1,2)$ \\
\hline Woody Parts of Oregano & $1.4(0.8,1.9)$ & $46.0(43.1,48.9)$ & $\begin{array}{c}77.3 \\
(75.3,79.4)\end{array}$ & $\begin{array}{c}22.3 \\
(19.8,24.8) \\
\end{array}$ & $2.1(1.3,3.0)$ \\
\hline Corn Cobs & $1.4(0.9,1.9)$ & $42.7(40.6,44.7)$ & $82.5(80.5,84.5)$ & $\begin{array}{c}27.0 \\
(24.4,29.6)\end{array}$ & $1.3(0.9,1.8)$ \\
\hline Corn Stalks & $1.5(1.0,2.1)$ & $46.3(43.7,48.9)$ & $60.7(56.5,64.8)$ & $\begin{array}{c}13.3 \\
(10.4,16.2)\end{array}$ & $3.1(2.3,3.9)$ \\
\hline Woody Parts of Potato & $0.7(0.4,0.9)$ & $58.0(55.8,60.2)$ & $\begin{array}{c}77.3 \\
(75.3,79.4)\end{array}$ & $32.0(30.1,35.2)$ & $0.7(0.6,0.8)$ \\
\hline Cotton Stems & $1.5(1.5,1.6)$ & $46.7(44.3,49)$ & $84.0(80.6,88.8)$ & $33.3(30.4,36.2)$ & $1.7(1.2,2.1)$ \\
\hline Sawdust Mix of Oak Spruce and Pine & $1.4(0.9,1.9)$ & $58.3(56,60.7)$ & $82.3(80.3,84.4)$ & $\begin{array}{c}27.3 \\
(24.8,29.8)\end{array}$ & $1.5(1.0,1.9)$ \\
\hline Cottonseed Fiber & $0.4(0.3,0.5)$ & ND & $87.3(85.6,89)$ & ND & $0.8(0.6,0.9)$ \\
\hline
\end{tabular}

$\mathrm{ND}=$ Not Detected

Table 2: Median (range) of the acid binding capacity ( $A B C$ ), water holding capacity (WHC) and pH of the investigated by-products.

\begin{tabular}{|c|c|c|c|c|c|c|c|}
\hline By-product & Walnut Shell & Olive Kernel & $\begin{array}{c}\text { Woody Parts of } \\
\text { Oregano }\end{array}$ & Corn Stalks & $\begin{array}{c}\text { Woody Parts of } \\
\text { Potato }\end{array}$ & Cotton Stems & $\begin{array}{c}\text { Sawdust Mix of } \\
\text { Oak Spruce and } \\
\text { Pine }\end{array}$ \\
\hline $\begin{array}{c}\mathrm{ABC} \\
(\mathrm{ml} \mathrm{HCl})\end{array}$ & $\begin{array}{c}3.2 \\
(3,3.3)\end{array}$ & $\begin{array}{c}3.1 \\
(3,3.2)\end{array}$ & $14.5(13.9,14.8)$ & $10.5(10.3,10.9)$ & $14(13.9,14.2)$ & $23.8(23.5,24.9)$ & $\begin{array}{c}3.6 \\
(3.5,3.8)\end{array}$ \\
\hline $\begin{array}{c}\text { WHC } \\
\text { (g water/ g sample) }\end{array}$ & $1.4(1.3,1.4)$ & $2.2(2.1,2.5)$ & $\begin{array}{c}5.8 \\
(5.7,6.1)\end{array}$ & $6.4(6.1,6.5)$ & $\begin{array}{c}6 \\
(5.8,6.2)\end{array}$ & $\begin{array}{c}7.2 \\
(7,7.3)\end{array}$ & $\begin{array}{c}4.2 \\
(4.1,4.3)\end{array}$ \\
\hline $\mathrm{pH}$ & $6.1(6.0,6.2)$ & $4.4(4.3,4.6)$ & $\begin{array}{c}5.8 \\
(5.7,6.1)\end{array}$ & $5.4(5.3,5.7)$ & $\begin{array}{c}6.0 \\
(5.7,6)\end{array}$ & $\begin{array}{c}6.5 \\
(6.4,6.6)\end{array}$ & $\begin{array}{c}4.4 \\
(4.3,4.8)\end{array}$ \\
\hline
\end{tabular}

the by-products evaluated. Due to the small sample sizes, the p-values of the above test were calculated by the Fisher's exact method. All analyses were performed in Stata 13.1 (Stata Statistical Software, College Station, TX) and evaluated at the $5 \%$ level of significance.

\section{Results}

Contents of by-products that have been studied in this work have shown a variety of characteristics as it is demonstrated in Table 1. For EE, ADF, percent lignin and ash no median of any by-product analyzed differed (lowest $\mathrm{p}=0.12$ ) from the respective overall medians of $0.99,47,29$ and 1.8. In contrast, NDF medians differed $(\mathrm{p}=0.002)$. The medians of NDF in corn cobs, cottonseed fiber, cotton stems and sawdust mix of oak spruce and pine were higher than the overall NDF median of 79.4 .

EE content was similar in lot of by-products (corn stalks, cotton stems, corn cobs, sawdust mix of oak spruce and pine), while the higher percentage is observed in olive kernel (8.5\%) and lower in cottonseed fiber $(0.4 \%)$. The measurement for lignin, ADF and NDF content has varied from not detected (ND) to $40 \%$, ND to $58 \%$ and 59 to $87 \%$ respectively. The higher values of lignin, ADF and NDF were observed in walnut shell (36.7\%), in sawdust mix of oak spruce and pine (58.3\%) and cottonseed fiber (87.3\%) respectively while lowest contents have been observed in cottonseed fiber (ND), cottonseed fiber (ND) and olive kernel (59\%) respectively.

The ash content (minerals) was less than $3.4 \%$ for all samples that have been analyzed with the higher value has been observed in olive kernel (3.4\%) and the lowest in woody parts of potato (ND).

In Table 2 the medians (range) of WHC, $\mathrm{pH}$ and $\mathrm{ABC}$ for the by-products that were analyzed were presented. The median WHC of cotton stems, corn stalks and woody parts of potato was higher $(\mathrm{p}=0.001)$ than the overall median WHC of 5.8. Cotton stems, woody parts of oregano and woody parts of potato had higher $(\mathrm{p}=0.001)$ median $\mathrm{ABC}$ than the overall $\mathrm{ABC}$ of 10.5. Lastly, the median $\mathrm{pH}$ of cotton stems, walnut shell and woody parts of potato was higher $(\mathrm{p}=0.01)$ than the overall median $\mathrm{pH}$ of 5.8. The measurement for $\mathrm{ABC}, \mathrm{WHC}, \mathrm{pH}$ measurements were varied from ND 3.1 to $23.8,1.4$ to 7.2 and 4.4 to 6.5 respectively. The higher values of $\mathrm{ABC}, \mathrm{WHC}, \mathrm{pH}$ were observed in cotton stems (23.8), cotton stems (7.2) and cotton stems (6.5) respectively while lowest values were observed in olive kernel (3.1), walnut shell (1.4) and olive kernel (4.4) respectively.

Analysis of feed parameters presented in Table 2 was not necessary for all by-products presented in Table 1. Only seven byproducts have been selected for analysis of parameters presented in Table 2 (ABC, WHC and $\mathrm{pH}$ ). The selection was based primary in their amount produced in the region as well as their close relation with other by-products presented in Table 2. Grape branches have not been analyzed because are not produced in large amounts in the region. Cottonseed fibers and corn cobs have not been analyzed because they have close relation (same plant) with cotton stems and corn cobs respectively that both are presented in Table 2 . 


\section{Discussion}

Our data reveal a variety in cellulose, hemicellulose and lignin content (Table 1) as those are reflected from ADF, NDF and lignin values respectively. We also observed significant differences in other characteristics such as $\mathrm{ABC}$ and $\mathrm{WBC}$ in feeds (Table 2). The variety of feed values of those by-product provide an excellent starting point for formulation of products with different characteristics and contents that could satisfy the different feed needs of different age groups of pigs. In particular the most promising by-products seem to be cotton stems, corn cobs, cottonseed fiber and the sawdust mix of oak spruce and pine.

Results from this work clearly demonstrate the high row fibers content that many by-products possess. Due to their availability and low cost, walnut shell, woody parts of potato, corn stalks and cotton stems can be used as additives developing a proper feeding system for livestock. Their high cellulose content $(>60 \%)$ and the presence of minerals give an alternative solution to the farmers to use these products in order to improve the animal production. It is demonstrated (Table 2) that some feed components bind more acid than others because of their high ABC. Feed components with high $\mathrm{ABC}$ values can absorb a lot of $\mathrm{H}^{+}$. As a result the $\mathrm{pH}$ of the stomach and the proximal digestive tract will remain high and the protein breakdown will be impaired in the stomach. In the jejunum and colon, excessive protein fermentation may occur, leading to the formation of toxin biogenic amines [33]. The concept of manipulating stomach acidity using components of low acid-binding or buffering capacity to starter feeds should be applied in our case, adding olive kernel or walnut shell with low values of $\mathrm{ABC}$. It is thought that ingredients of low $\mathrm{ABC}$ could then be used to formulate a starter diet in such a way that gastric acidity would be promoted.

The WHC is particularly important in reducing feed intake in ad libitum feeding systems in order to prevent too much weight gain; therefore the satiation effect occurs very quickly and in the same time the desired feed intake is regulated [17]. The most promising product regarding this property seems to be the cotton stem with superior WBC than the rest of the by-product followed by corn stalks. Byproducts with high NDF content can be combined with other byproduct with high $\mathrm{WBC}$ values to achieve a product with desirable properties for different age groups of pigs.

Also, with by products containing high soluble fiber levels (hemicelluloses), the activity of intestinal bacteria with cellulolytic and hemicellulolytic activities is generally increased. Local agricultural by products such as cotton stems or corn stalks could be an ideal solution in animal feeding. EE is relative low in all samples except from olive kernel, indicating that this particular by-product has higher calories content. The ash analysis reflects mineral content which will require further analysis (individual metals and minerals) in order to be fully appreciated, although a first assumption is that walnut shell and olive kernel would provide much more minerals than other by-products.

All those by-products can be found in significant amount in the region of Thessaly. Cotton is the major agricultural product of the region with corn being the second major product. Mountains are in close proximity and wood processing industries are present in significant numbers in the region. This give a constant supply of sawdust mix since the trees like oak and pine are endogenous species and thrive in the area.

\section{Conclusions}

A lot of local agricultural by-products can be used as additives in conventional feeds because of their high content in raw fibers. Concentrated raw fiber products can be produced by a lot of local by-products and benefit environment, local economy and farmers' livelihood. The intensive system of livestock production and the high cost of conventional feeds have aroused several interests in the search for cheaper feedstuffs as substitutes. Producers are continuously looking for ingredients with a value added and local agricultural byproducts present a possible solution for animal feed because of their high content in raw fibers. This is currently satisfied with products imported from North Europe. Shipping of those products has economical as well as environmental (carbon footprint) cost. The use of local feeds can preserve and protect the environment and promote the efficiency of natural local resources in land and mountainous areas as well as providing an additional income to local farmers. They can use the agricultural crop by-products as feeds or energy material instead of been considered as useless waste. This product can reduce carbon footprint of both crop and animal production in agriculture sector.

\section{References}

1. Swidiq M, Jolly K, Emmanuel Z, George L (2012) Utilization of crop residues and agro-industrial by-products in livestock feeds and feeding systems of Uganda. Int J Biosci 2: 82-89.

2. Chen MC (1977) The utilization of agricultural by-products for livestock. Agric Assoc China 100: 34-41.

3. Bello AO (1984) The use of agro industrial by-products in livestock feeding. Nigerian J Anim Prod 11: 84-86.

4. Kim HS, Yoon SK, Cho CH, Lee KJ, Lee SC (1992) Studies on the improvement of feed efficiency using food industry by-products. Annual Report Livestock Experiment Station Korea.

5. Rozeboom DW, Shaw DT, Tempelman RJ, Miguel JC, Pettigrew JE, et al. (2005) Effects of mannan oligosaccharide and an antimicrobial product in nursery diets on performance of pigs reared on three different farms. J Anim Sci 83: 2637-2644.

6. Brouns F, Edwards SA, English PR (1995) Influence of fibrous feed ingredients on voluntary intake of dry sows. Anim Feed Sci Technol 54: 301-313.

7. Danielsen V, Vestergaard EM (2001) Dietary fibre for pregnant sows: effect on performance and behaviour. Anim Feed Sci Technol 90: 71-80.

8. Rowell RM (2012) Moisture properties. In: Handbook of wood chemistry and wood composites, Second edition. CRC Press, New York.

9. Calvo-Flores FG, Dobado JA (2010) Lignin as renewable raw material ChemSusChem 3: 1227-1235

10. Jiang G, Nowakowski DJ, Bridgwater AV (2010) A systematic study of the kinetics of lignin pyrolysis. Thermochim Acta 498: 61-66.

11. Menon V, Rao M (2012) Trends in bioconversion of lignocellulose: biofuels, platform chemicals \& biorefinery concept. Prog Energ Combust Sci 38: 522550 .

12. Gillespie JR (1987) Animal nutrition and feeding. Delmar Publishers, Inc.

13. FAO (1980) The classification of world livestock systems. A study prepared for the Animal Production and Health Division of FAO.

14. FAO (1994) Integrating livestock and crops for the sustainable use and development of tropical agricultural systems. AGSP-FAO. 
ISSN: $2325-4645$

15. Aguilera JF (1989) Use of agroindustrial by-products in the feeding of ruminants. Rev Argentina de Prod Anim 9: 253-267.

16. Stern MD, Ziemer CJ (1995) By-product feeds as energy sources for ruminants. Prof Anim Sci 11: 51-66.

17. Wolfgang M, Backers T (2003) Concentration breeds success for raw fibers. Feed mix Volume 11 Number 2.

18. Bolhuis JE, van den Brand $\mathrm{H}$, Bartels $\mathrm{AC}$, Oostindjer $\mathrm{M}$, van den Borne $\mathrm{JJ}$, et al. (2010) Effects of fermentable starch on behaviour of growing pigs in barren or enriched housing. Appl Anim Behav Sci 123: 77-86.

19. Meunier-Salaun MC, Edwards SA, Robert S (2001) Effect of dietary fibre on the behaviour and health of the restricted fed sow. Anim Feed Sci Technol 90: 53-69.

20. Guillemet R, Dourmad JY, Meunier-Salaun MC (2006) Feeding behavior in primiparous lactating sows: impact of a high-fibre diet during pregnancy. $J$ Anim Sci 84: 2474-2481.

21. Holt JP, Johnston LJ, Baidoo SK, Shurson GC (2006) Effects of a high-fiber diet and frequent feeding on behaviour, reproductive performance, and nutrient digestibility in gestating sows. J Anim Sci 84: 946-955.

22. Ramonet Y, Meunier-Salaün MC, Dourmad JY (1999) High-Fiber diets in pregnant sows: digestive utilization and effects on the behavior of the animals. J Anim Sci 77: 591-599.

23. Whittaker X, Edwards SA, Spoolder HA, Lawrence AB, Corning S (1999) Effects of straw bedding and high fibre diets on the behaviour of floor fed group-housed sows. Appl Anim Behav Sci 63: 25-39.

24. de Leeuw JA, Bolhuis JE, Bosch G, Gerrits WJ (2008) Effects of dietary fibre on behavior and satiety in pigs. Proc Nutr Soc 67: 334-342.

25. Rainbird AL, Low AG (1986) Effect of various types of dietary fibre on gastric emptying in growing pigs. Br J Nutr 55: 111-121.

26. Varel VH, Fryda SJ, Robinson IM (1984) Cellulolytic bacteria from pig large intestine. Appl Environ Microbiol 47: 219-221.

27. Varel VH, Yen JT (1997) Microbial perspective on fibre utilization by swine. J Anim Sci 75: 2715-2722.
28. Yen JT, Nienaber JA, Hill DA, Pond WG (1991) Potential contribution of absorbed volatile fatty acids to whole-animal energy requirement in conscious swine. J Anim Sci 69: 2001-2012.

29. Bach Knudsen KE, Jensen BB, Andersen JO, Hansen I (1991) Gastrointestinal implications in pigs of wheat and oat fractions. 2. Microbial activity in the gastrointestinal tract. Br J Nutr 65: 233-248.

30. Mahan D (2005) Feeding the sow and piglet to achieve maximum antioxidant and immune protection. In: Taylor-Pickard JA, Taylor-Pickard JA, Tucker LA, (Eds). Re-defining mineral nutrition. Nottingham University Press, Nottingham, pp. 63-73.

31. Damgaard Poulsen H (1993) Minerals for sows. Significance of main effects and interactions on performance and biochemical traits. PhD Thesis, University of København, Denmark.

32. Spurlock ME, Frank GR, Willis GM, Kuske JL, Cornelius SG (1997) Effect of dietary energy source and immunological challenge on growth performance and immunological variables in growing pigs. J Anim Sci 75: 720-726.

33. Makkink C (2001) Acid binding capacity in feedstuffs. Feed Int: 24-27.

34. Bolduan G, Jung H, Schnabel E, Schneider R (1988) Recent advances in the nutrition of weaner pigs. Pig News Inf 9: 381-385.

35. AOAC, Official Method of Analysis (1990) 15th edition. Association of Official Analytical Chemists Washington DC.

36. AOAC, Official Method of Analysis (2002) Method 934.01. Loss on drying (moisture) at $95-100^{\circ} \mathrm{C}$ for feeds. AOAC International Arlington VA.

37. AOAC, Official Method of Analysis (2005) Method 920.39. Fat (crude) or ether extract in animal feed, (18 thedn). AOAC International, Gaithersburg, MD.

38. Van Soest PJ (1994) Nutritional ecology of the ruminant, second edition. Cornell University Press, Ithaca, NY.

39. Jasaitis DK, Wohlt JE, Evans JL (1987) Influence of feed ion content on buffering capacity of ruminant feedstuffs in vitro. J Dairy Sci 70: 1391-1403.

40. Robertson JA, Eastwood MA (1981) An investigation of the experimental conditions which could affect water-holding capacity of dietary fibre. J Sci Food Agric 32: 819-825.

\section{Acknowledgements}

This work was funded by the research project entitled "Claw lesions, longevity and welfare of group housed sows". Funding body: NSRF 2007-2013 (Cooperation 2011). 